\title{
ИССЛЕДОВАНИЕ ГЕОЛОГИЧЕСКИХ СРЕД ПО РАССЕЯННЫМ И ДИФРАГИРОВАННЫМ ВОЛНАМ, ВЫДЕЛЕННЫМ ИЗ ВОЛНОВОГО ПОЛЯ 2D МОГТ
}

Кремлев А.Н., Ерохин Г.Н., Стариков Л.Е., Зверев М.А. (‡ОНИИ ИТ, г. Ханты-Мансийск)

В Югорском НИИ информационных технологий (г. Ханты-Мансийск) получены новые результаты в теории волновых процессов, позволяюшие путем математически корректного вычитания из полного волнового поля отраженньх волн, выделить из него дифрагированные и рассеянные волны, являющиеся для изучения зон трещиноватости целевыми.

Осуществив эффективное разделение полей отраженных и рассеянных волн, авторы смогли «увидеть» изображение геологической среды в рассеянных волнах, энергия которых составляет малую часть общей энергии отраженных сейсмических волн.

Особенностью технологии, созданной в ЮНИИ ИТ, является то, что метод реализован в виде программного обеспечения для обработки стандартньх 2D сейсморазведочныт данных. Метод получил название Волнового аналога метода ОГТ (ВОГТ). Метод ВОГТ является оригинальным методом престековой миграцих, который позволяет получать как традиционные временные разрезы, так и временные разрезы дифракторов, содержащие изображение рассеиваюших элементов среды.

Основное достоинство метода ВОГТ - возможнность изучения геологических сред в рассеянных (дифрагированныт) волнах. Разрез дифракторов (рассеивателей) адекватно описывает распределение В геологической среде нерегулярных акустических неоднородностей. Он позволяет выявлять зоны трещиноватости, кавернозности, карстования, а также зоны повьшенной шероховатости отражающих горизонтов, как в осадочном чехле, так и в породах фундамента.

В настоящее время в ЮНИИ ИТ сформировалась некоторая технология обработки $2 \mathrm{D}$ сейсморазведочных данных на базе метода ВОГТ и суперкомпьютера Sun Fire 15000. Эта технология включает в себя:

Предварительную и стандартную обработку данных МОГТ;

Специализированную обработку сейсморазведочных данных по методу ВОГТ с получением 2-х независимых разрезов:

традиционного мигрированного временного разреза рефлекторов лей).

временного разреза дифракторов (рассеивате-

Пункт 1 выполняется с использованием обрабатывающего пакета ProMAX, выполнение пункта 2 базируется на оригинальньх разработках и программном обеспечении, созданньх в Югорском научно-исследовательском институте информационных технологий (г. Ханты-Мансийск).

Метод разработан для прямого прогноза зон распространения коллекторов нетрадиционного типа в магматических, карбонатных и глинистых породах. Для прогноза используются материалы стандартной сейсморазведки. Метод промел тестирова-

ние в различных регионах России: ЗападноСибирской, Волго-Уральской и Лено-Тунгусской НГП. Объектами исследований являлись резервуары различного стратиграфического диапазона (от рифея до коры) и различного вещественного состава (магматические, карбонатные и глинистые породы). Результаты тестирования показали высокую эффективность метода и возможность его использованияя для прогноза зон распространения коллекторов нетрадиционного типа в промышленных масштабах.

Представляется, что метод будет востребован в практике геолого-разведочных работ для воспроизводства минерально-сырьевой базы ХантыМансийского автономного округа, а также будет способствовать повышению эффективности геолого-разведочных работ в Лено-Тунгусской НГП Сибирской платформы и Волго-Уральской НГП. Метод позволит вовлечь в разработку нефтегазовый потенциал перспективных стратиграфических объектов. 